\title{
THE LOCAL CREATIVE ADS ON SRITANJUNG FM TO INCREASE FINANCIAL REVENUE DURING COVID-19 PANDEMIC
}

\author{
${ }^{1)}$ Zainal Abidin Achmad, ${ }^{2)}$ Juwito, ${ }^{3)}$ Muhammad Saud \\ ${ }^{1,2)}$ Universitas Pembangunan Nasional Veteran Jawa Timur, Indonesia \\ ${ }^{3)}$ International Islamic University, Pakistan \\ 1,2) Jln. Rungkut Madya No.1, Gunung Anyar, Surabaya, Jawa Timur 60294, Indonesia \\ ${ }^{3)} \mathrm{H}-10$, Islamabad, Islamabad Capital Territory 44000, Pakistan
}

Received on August, 02 ${ }^{\text {nd }}, 2020 /$ Accepted on September, 27 $7^{\text {th }}, 2020$

\begin{abstract}
The COVID-19 pandemic condition requires private radio managers' creativity, one of which is the Sritanjung FM in the Banyuwangi Regency. Uniquely, as a cultural radio, Sritanjung FM advertising revenue increased precisely during the COVID-19 pandemic. This research uses a virtual ethnographic method that collects data offline and online. Researchers conducted direct observations of Sritanjung FM in Rogojampi District, Banyuwangi Regency, and conducted a virtual search through audio streaming, Facebook, and WhatsApp. In this study, informants amounted to four people, two from radio staff, one cultural expert, and one loyal listener. The results showed that the number of local advertisers and the frequency of local advertisements had increased three times. The internal causes include the creativity of Sritanjung FM in creating cultural programs and religious programs, creativity in the designing messages for ads spots, and uniqueness of using local language that match the COVID-19 theme. Local culture advertising creativity can be felt as the main taste of content that has relevance to postmodernism studies. External causes include the need for a business breakthrough to maintain income, the socio-cultural context of Osing ethnicity for the Banyuwangi people. Combined interest between local advertisers, strong Osing culture identity, and advertisers' creativity make Sritanjung FM experience a surge in revenue from local advertisers during the COVID-19 pandemic.
\end{abstract}

Keywords: COVID-19, cultural radio, local creative ads, postmodernism, virtual ethnography.

\begin{abstract}
ABSTRAK
Pandemi COVID-19 membutuhkan kreativitas pengelola radio swasta untuk bertahan hidup, salah satunya adalah Sritanjung FM di Kabupaten Banyuwangi. Uniknya, sebagai radio budaya, pendapatan iklan Sritanjung FM justru meningkat saat pandemi. Penelitian ini menggunakan metode etnografi virtual yang mengumpulkan data secara offline dan online. Peneliti melakukan pengamatan langsung di Sritanjung FM di Kecamatan Rogojampi, Kabupaten Banyuwangi, dan melakukan pencarian virtual melalui audio streaming, Facebook, dan WhatsApp. Jumlah informan dalam penelitian ini ada empat orang, dua dari staf radio, satu ahli budaya, dan satu pendengar loyal. Hasilnya menunjukkan bahwa jumlah pengiklan lokal dan frekuensi iklan lokal telah meningkat tiga kali lipat. Secara internal, penyebabnya adalah kreativitas dalam menciptakan program budaya dan program keagamaan, kreativitas dalam merancang pesan untuk spot iklan, dan keunikan menggunakan bahasa lokal untuk iklan baca. Kreativitas iklan berbudaya lokal dapat dirasakan menjadi selera utama konten memiliki relevansi dengan kajian posmodernisme. Penyebab eksternalnya adalah kebutuhan para pengiklan lokal untuk mempertahankan bisnis mereka, dan konteks sosial-budaya kecintaan masyarakat Banyuwangi kepada budaya Osing. Kombinasi kepentingan antara pengiklan lokal, identitas budaya Osing, dan kreativitas pengiklan, membuat Sritanjung FM mengalami lonjakan pendapatan iklan.
\end{abstract}

Kata kunci: COVID-19, etnografi virtual, kreatifitas iklan lokal, postmodernisme, radio budaya.

*Corresponding Author:
E-mail: z.abidinachmad@ upnjatim.ac.id 


\section{INTRODUCTION}

The first radio in the Banyuwangi Regency, which has an identity of Osing culture, is Sritanjung FM and declared itself as ethnic radio (PRSSNI Jawa Timur, 2018). It always produces content by relying on Osing ethnicity character. Osing language is the primary broadcasting language besides Bahasa Indonesia. Like talk shows, news, and music hours, some programs, are bilingually using both languages (Bahasa Indonesia and Osing language). Specifically, Osing language use for delivering cultural programs such as Sritanjung Jenggirat Tangi, Dendang Banyuwangi, and Geredoan. Also, for delivering all religious (Islamic dakwah) programs (Achmad, 2020c).

Cultural radios are private radios with cultural programs delivering in local languages more than four hours a day (Achmad \& Ida, 2019). They have an unequal comparison of ads revenue between local advertisers and national advertisers, 70 percent from local advertisers, and 30 percent of ads revenue from national advertisers (Achmad, 2019). As a cultural radio, Sritanjung FM can survive and reap much revenue, precisely from local advertisers. The embedding motto of Radioe Lare Osing is the main strength of Sritanjung FM (Arps, 2009).

Because of having local content, Sritanjung FM has the most significant number of listeners in Banyuwangi Regency. According to the latest listeners' research in 2018, Sritanjung FM has 302,479 listeners (data from the marketing division of Sritanjung FM). Its broadcast coverage covers the entire Banyuwangi area with an area of $5,782 \mathrm{Km} 2$ and covers Gilimanuk, Melaya, and Negara (parts of Bali's island).

Banyuwangi Regency is a regency area with the highest number of FM channels, ten canals, compared to other regencies in Indonesia. Ten FM radio stations are broadcasting in the Banyuwangi Regency airspace, which makes it the regency with the most stringent radio competition level in Indonesia (KPID Jawa Timur, 2017). The high level of private radio competition in the Banyuwangi Regency makes Sritanjung FM endless to innovate to maintain broadcast quality and maintain listener loyalty. Sritanjung FM is a pioneer radio in digitizing the management system of advertising reporting integration, facilitating mutual control between the marketing department, the broadcast department, and the production department to ensure certainty of program broadcasting and ad broadcasting, in records per second.

The positioning strategy of Sritanjung FM as a pioneer of Osing language broadcasting in Banyuwangi has been through a very mature consideration. The decision to use this positioning strategy involves analysis from Osing's cultural experts. The primary consideration is the distinctiveness of Banyuwangi people who have a love of local tastes. Everything that contains Osing culture always gets the attention and likes of the Banyuwangi people.

Sritanjung FM's dependence on Osing culture experts is evident in naming programs, coverage of the tourism agenda about Osing culture, the use of Osing language by announcers, Osing language policy for Islamic da'wah programs, and the use of Osing language in ad spots and adlib (interview with Mr. Juwono, informant 1, 23 February 2020).

In previous research, Achmad found several potential local advertisers that become permanent clients of Sritanjung FM (Achmad, 2020c). Nevertheless, in the first month of pandemic COVID-19 or March 2020, some local advertisers have stopped their contracts. The economic condition was not good enough for a business to do promotion and buy air times. Uniquely, by doing virtual observation, researchers found that some new advertisements come from some new local advertisers performed in all programs of Sritanjung FM during May and June 2020.

Then researchers followed up with a discussion with loyal listeners, part of the 'Sritanjung FM Fans' WhatsApp group. This kind of anomaly is interesting to observe. What has exactly happened in Sritanjung FM? Why local advertisers come up with more numbers and advertisements during the COVID-19 pandemic?

\section{RESEARCH METHOD}

This research combines data from previous field studies with virtual observation, following qualitative research procedures using virtual ethnographic 
methods, as carried out by Christine Hine. The strength of Christine Hine is her efforts to continue to develop this method by developing procedures, stages, and applications in several research subjects(Hine, 2004, 2005, 2015). Two types of virtual ethnographic research fields become the area of data collection, namely the real field and virtual field(Achmad \& Ida, 2018).

In this research, real fields include radio studios, workspaces, broadcast technology devices, a gathering place for listeners and broadcasters, and the socio- cultural surroundings of Sritanjung FM. This research's virtual fields include Facebook accounts of Sritanjung FM and informants, content streaming broadcasts, and WhatsApp group. Using these two fields is to obtain various information about the dynamics of life, behavior, and social relations of the informants. The need for time on virtual ethnographic research must consider the adequacy of interactions with community members on online and offline social networks (Achmad \& Ida, 2018; Sade-Beck, 2004; Turkle, 2011)

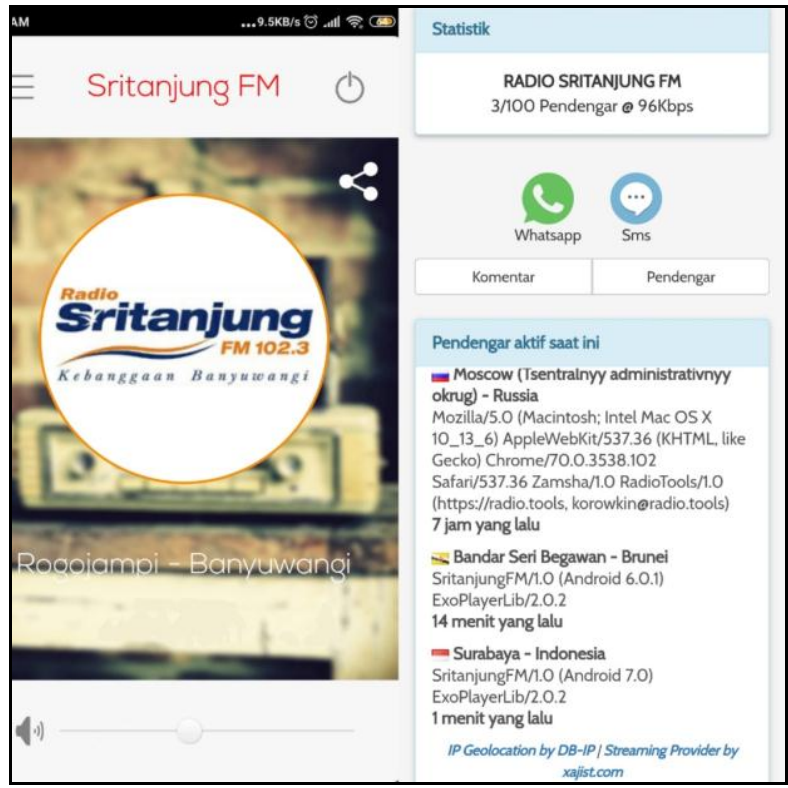

Figure 1: Sritanjung FM's sudio streaming application for android mobile phone. (Source:https://play.google.com/store/apps/details?id=com.xajist.sritanjungfm.)

As one of the principles of intermittent or non-sequential virtual ethnographic research (Hine, 2004), this research is a continuation of the offline period in the range of January until March 2020. The virtual tracing held out in three months of the COVID-19 pandemic, namely April until June 2020. Researchers collect advertising data, such as advertisers' names, frequency of advertisements, the content of messages in the advertisement, and the ins and outs of making ad spots and reading advertisements.

This research involved four informants, including Mr. Juwono (cultural expert, informant 1), Mr. Luki (marketing, informant 2), Mrs. Dessy (announcer, informant 3), and Mrs. Masita (loyal listener, informan 4). This study applies the researchers' participatory involvement to immerse themselves in informant activities related to making programs and evaluating advertising content. Researchers and informants interact with each other in the real world and the virtual world. Participative involvement in virtual ethnographic research clarifies and confirms the truth of data and avoids falsifying the informants' identity (Achmad \& Ida, 2018; Angelone, 2018; Hine, 2004). For this virtual ethnographic study, the researchers revealed their identity as researchers by using personal social media accounts and personal cellular telephone numbers.

The researchers used one reliable qualitative research strategy because this study was interconnected with various theories since the beginning of the data collection process. Some theories such as information society, mass society, the political economy of mass media, and the 
network society will intersect with the study of consumer culture and postmodernism. Grounded strategy means that the essence of qualitative research recognizes the constitutional theory of the research subject. In short, theories are always present and are attached to data (Howitt \& Cramer, 2011; Walliman, 2011).

\section{RESULTS AND DISCUSSION}

The Sritanjung FM aligns with Osing culture due to the strong historical ties with the Rogojampi region. The location of the Sritanjung FM studio in the Rogojampi District influenced the strong identity of Osing, which is attached to the name Sritanjung. Historical records show that the Rogojampi area was once the center of the Blambangan kingdom during the reign of Prince Adipati Danureja (1698-1736). As the King of Blambangan, Prince Adipati Danureja built a new palace in the KebrukanLateng area, which is now part of the Rogojampi District area (Salamun, Sumintarsih, \& Wuryansari, 2015).

Rogojampi is the name of the region, which comes from two words, namely Ronggo and Jampi. Ronggo is the name of a leader of a group of war troops, while Jampi has the meaning of medicine or medication. In the past, there was a rebellion by King Blambangan against the Majapahit Kingdom. The Majapahit King sent a Ronggo to quell the rebellion. After the conquest of Raja Blambangan, Majapahit needed to control the government in Blambangan. The Ronggo, who contributed significantly, received an order to control the tranquility of the situation temporarily. When the Majapahit army got charges to return, the Ronggo decided to stay in Blambangan and live his life as a medical expert or Jampi. Since that time, the Ronggo had the title Ronggo Jampi. The Ronggo Jampi's medical expertise is well known throughout Blambangan to Bali.

The area where Ronggo Jampi lives is named Rogojampi. Giving the name of an area has a meaningful relationship with local history that occurred in the past(Yurisma \& Bahruddin, 2020). As proof love of the Ronggo Jampi in Blambangan is his request to live the end of his life in Blambangan. The tomb of the Ronggo Jampi, which is in the public cemetery of Krajan Village, is still in good condition and has become one of the pilgrimage destinations of Banyuwangi residents and its surroundings (Mursidi \& Soetopo, 2018).

The Rogojampi area, since the Blambangan kingdom in the past, has a social structure that is very diverse, multicultural and upholds tolerance. The multicultural character has become the identity of the community in the Rogojampi area. Various ethnicities, namely Osing, Javanese, Balinese, and Madurese, can co-exist in harmony.One of the reasons for the strong character of multiculturalism is many inter-ethnic marriages (Fernando, Sya, \& Marta, 2019).

Even in terms of religious diversity, there are several religions, namely Islam, Hinduism, Buddhism, and Christian, living in harmony. The residents of Rogojampi, who are mostly Muslim, practice a tolerant life very well. In the history of Rogojampi, there has never been an inter-ethnic or interreligious conflict (Faizah, 2011).

The dominance factor of Muslims in Rogojampi also influenced the content of the Sritanjung FM program. Islam, as the majority of religion, is a protector for the minority. This social capital has become a part of community life in Rogojampi, since becoming the center of the spread of Islam since the collapse of Majapahit power in the Blambangan area.

Tolerance and protection that are characteristic of Islam are reflected in Islamic da'wah programs at Sritanjung FM. The entire program design and content of Islamic da'wah aim to establish silaturrahim among adherents of Islamic religion, realize Ukhuwah Islamiyah, and maintain interfaith tolerance (Mr. Juwono, informant 1, 23February 2020).

The respect and love of Banyuwangi citizens towards Islam and Osing culture are two sides of a coin that are always present together and inseparable. This condition because of historical factors that are part of Rogojampi residents' lives and the Banyuwangi Regency in general. Sritanjung FM seeks to meet Banyuwangi residents' needs for the content of the Islamic da'wah program and Osing culture. Not surprisingly, the loyal listeners always support cultural programs and da'wah programs at Sritanjung FM, through broadcasts on-air or various offair events. 
As a cultural radio that has the most listeners base in Banyuwangi, Sritanjung FM supports the listeners' community's effort to interact and participate, including the insistence of listeners that Sritanjung FM utilizes Facebook and audio streaming as broadcast support Technology. Facebook by Sritanjung FM is encouragement from young listeners, who are in the age range of 20-30 years (Mr. Luki, informant 2, 24 February 2020). Listeners in this age group, most of whom were born in the 2000s, have a habit of being active in searching for information through social media (Dresang \& Koh, 2009). As part of the generation that lives in the digital era, these young radio listeners generally have the characteristic of being open to access the web as a source of information (Achmad, 2020c).

The decision to adopt Facebook is very familiar to young people and provides facilities for tracking and searching through mention and hashtags. Moreover, it requires little data quota to share photos and videos (Achmad, 2019; Al-Rawi, 2016; Ellison, Steinfield, \& Lampe, 2007).

This process is proof of one of the principles of mediamorphosis, which is the delayed adoption of technology. Adopting technology is not possible immediately when the technology is discovered; its nature is a delay in applying (Achmad, 2020b; Fidler, 1997).

Dissemination of Osing cultural content by Sritanjung FM through Facebook shows its role as a media institution that integrates its motives with listeners and fellow members of the network society. Facebook offers its role as a media institution that integrates its motives with listeners and fellow members of the network society. Some of the motives met in network society are the motives of listeners to access content, listeners' motives for satisfying needs, managers' motives for increasing participation and interaction, social motives to strengthen shared identity (Salo, Lankinen, \& Mäntymäki, 2013).

The Facebook platform is essential for Sritanjung FM broadcasts because it provides a virtual space for listeners to communicate, exchange cultures, share knowledge, and interact without recognizing distance separation. Facebook becomes an intercultural understanding of its users(Fensi, 2019; Sawyer \& Chen, 2012).
This research has dealt with the study of postmodernism at three points. First, when a private radio that has a cultural identity and relies on cultural programs can survive and even get financial benefits beating private radios that rely on a pop format (Achmad, 2019; Achmad \& Ida, 2019). In this condition, cultural radio can deconstruct a significant narration in the radio world that popular content radio is more sold than local culture radio. This significant narrative reversal is part of postmodern studies (Raj Singh, 2011).

Second, when radio broadcast content produces local culture, this illustrates the emergence of social arrangements about the importance and power of mass media to arouse local culture to be able to block the pace of popular culture and global culture(Featherstone, 1995). Radio listeners can define themselves as having Osing ethnic identity.

Third, when Sritanjung FM enters the virtual world with Facebook, Audio Streaming, and WhatsApp, it immerses itself in postmodern culture. Relationships, communication, interaction, the familiarity used to occur in real terms experienced a shift towards virtual. The real conditions that occur in the virtual world are called virtual reality (Featherstone, 2007).

The Sritanjung FM program, which has the advantage of Islamic and Islamic missionary preaching, always attracts local advertisers. There are almost no programs that do not get advertisements. Three Islamic da'wah programs always get full ad slots, namely morning da'wah, evening da'wah, and Titian Senja. Morning da'wah is a broadcast of recorded religious lectures from famous preachers in Indonesia, or sometimes live broadcast lectures from mosques in Banyuwangi. Da'wah afternoon at 16:30 WIB contains a review of the book Al-Hikam by $\mathrm{KH}$ Yazid Bustomi from Pasuruan, and this program is a recorded broadcast. Book AlHikam is a compulsory Islamic study material for Santri in various boarding schools in Banyuwangi. Titian Senja at 17.00 WIB is a recording broadcast of the reading holy verses of the Qur'an. Another content as an Islamic characteristic of Sritanjung FM is Time Signal, which is a short recitation of Tilawah extracts from verses from the Qur'an and selected hadiths, as a marker of 
changing hours (Ms. Dessy, informant 3, 24 February 2020).

The three names of cultural programs whose ad slots are always full are Geredoan,Dendang Banyuwangi, and Sritanjung Jenggirat Tangi. The Geredoan Program, 13.00-15.00 WIB, is an interactive broadcast by opening direct telephone connections on-air from listeners to broadcasters. This program is one hundred percent using Osing language, an informal style of speaking, containing jokes with announcers and jokes among listeners. Geredoan has the original meaning of Osing speaking jokes between two or more people. The distinctive feature of the Geredoan program is that it requires an interactive onair listener to initiate greetings by conveying wangsalanor poem, and basananor parable. Geredoan is a characteristic of Osing ethnicity.

The Dendang Banyuwangi program contains the latest Banyuwangi Gending (song) broadcasts. The distinctive marker of Banyuwangi songs is traditional music called Kendang Kempul. In the latest development, Kendang Kempul is experiencing other musical elements such as patrol, janger, koplo, dangdut, jaranan, reggae, pop, and hip hop (Mr. Juwono, informant 1, 23 February 2020).

While the Sritanjung Jenggirat Tangi program at $07.00-0800 \mathrm{WIB}$, presents local information from coverage around Banyuwangi from field reporters, with interludes national or international information sourced from the internet. The language of instruction in this program is a mixture of Bahasa Indonesia and Osing languages. Furthermore, one of the bestselling talk show programs is Simponi keluarga. It is a one-hour dialogue program that is very effective for product promotion, service promotion, and new policy socialization of government or private agencies.

The one hour time does not take the form of blocking time from one advertiser and closes another incoming ad. This dialogue program is in high demand by homemakers and domestic workers (Ms. Masita, informant 4, 25 February 2020).

Several exciting themes of dialogue in the Simponi Keluarga talk show for the listeners are promo songs or music albums, socialization of government programs, product launch promos, and parenting. The theme of parenting talk show always gets extraordinary interest because of the importance of family values. Parents and family are the essential factors in shaping the child's personality and preventing future social problems (Ms. Dessy, informant 3, 24February 2020). Family harmonization is the best prevention of potential social problems. Many child personality disorders occur due to family disharmony or lack of parental attention (Achmad, Kinan, \& Artaria, 2018; Achmad, Mardliyah, \& Pramitha, 2018; Achmad, Wiranata, \& Mardliyah, 2016)

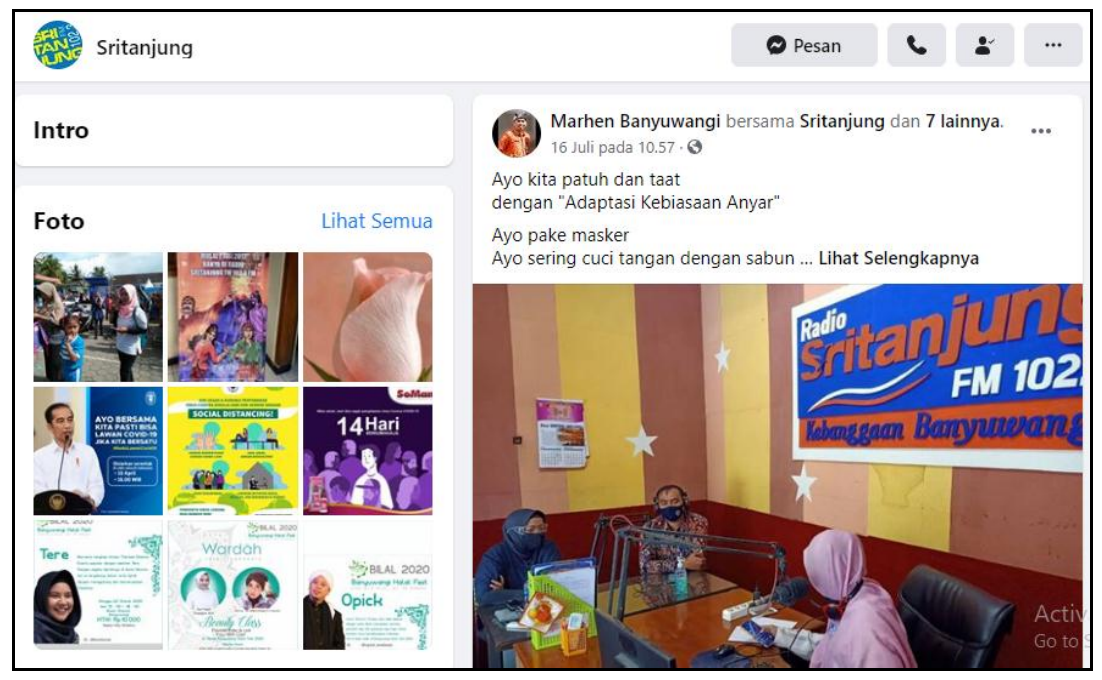

Figure2: Talkshow program, Simponi Keluarga.

(Source:https://www.facebook.com/profile.php?id=100010926105561, accessed: 16 Juli 2020). 
Besides having excellence in programs to the cultural identity of Osing, and the use of technology, the other factors of Sritanjung FM superiority are the ability of creative workers in producing advertisements. The creative process of making advertisements gives local advertisers to trust their products to advertise on Sritanjung FM. This research found some exciting findings on several advertisements on Sritanjung FM during the COVID-19 pandemic period, especially from April to June 2020. The frequency of advertisements increased significantly per week. Moreover, the number of local advertisers grew up.

The critical factor is collaborative work among marketing, production, and broadcasters who act as copywriters, adverts, screenplays, voice recorders, and narrators. As a creative team, they find the best tricks and tips to increase advertising revenue. Based on a virtual search through Facebook and audio streaming, researchers found several tricks and tips.
They were offering revised ad spots and adlibs by adding messages relevant to the COVID-19 pandemic issue. Sales of ad packages accompany ad revision offers; for example, revised advertisements are free of charge if local advertisers increase advertising frequency. They offered the creation of new ad spots with the COVID-19 pandemic theme with the bonus of adlibs. They also provided ad packages at exclusive prices with a certain number of ad frequencies. The result is an increase in advertisements' frequency and increased advertising revenue (Ms. Dessy, informant 3, 24 February 2020).

The advertising creativity on Sritanjung FM has a significant impact on the increasing number of local advertisers. Some new local advertisers appear on various broadcast programs; they are furniture shops, automotive repair services, restaurants or cafes, and laundry services. Furthermore, old local advertisers increased their advertisements' frequency.

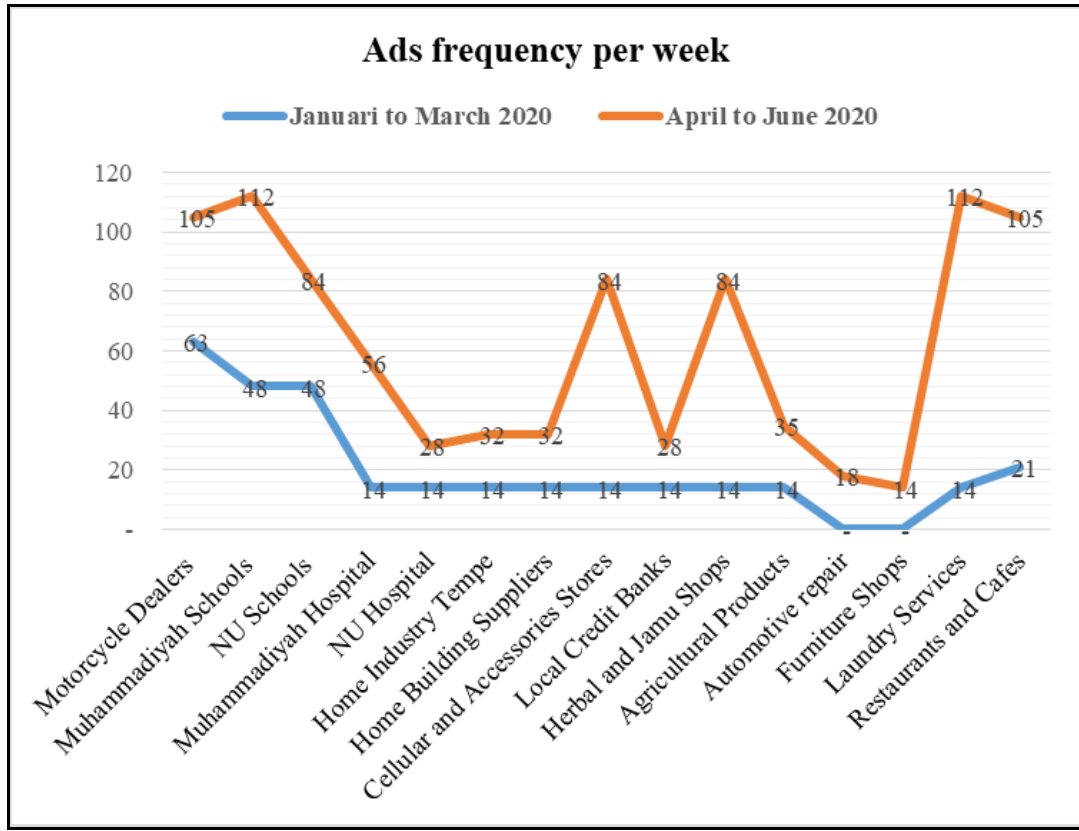

Figure 3: Comparison of ads frequency from local advertisers on Sritanjung FM. during COVID-19 pandemic. (Source: content monitoring from audio streaming)

The following are some creative ads messages for new local advertisers. (1) Furniture shops offered discount prices and light installments for purchase during the COVID-19 pandemic. They prepared a purchasing service via WhatsApp and free shipping service for certain distances. (2) Automotive repair service conveyed the completeness and sophistication of workshop equipment. Offering a home service for minor damage and offering pick up and delivery services for substantial damage. 
Restaurants and cafes offered a special menu of lunch and dinner package for groups (family or office) with free delivery service.

Some old clients, such as motorcycle dealers, Tempe home industry, home building suppliers, herbal shops, cellular and accessories shops, are willing to increase the frequency of ad spots because they get a free of charge for making new ad spots and getting bonus adlibs (30 seconds). Adlibs contains messages about preventing corona transmission and new health protocol habis (Mr. Luki, informant 2, 24 February 2020).

Other local advertisers show competition for the number of advertisements between Nahdlatul Ulama Banyuwangi Hospital and Muhammadiyah Rogojampi Hospital. Likewise, educational institutions under the Regional Board of Nahdlatul Ulama Banyuwangi and the Regional Board of Muhammadiyah Banyuwangi. The frequency of advertisements increased rapidly during the COVID-19 pandemic. The production of advertising spots, adlibs, cultural programs, and Islamic da'wah programs by Sritanjung FM is a cultural industry (Rahim \& Pawanteh, 2010).

The Sritanjung FM creative team also created unique advertising spots and adlibs for private Islamic schools owned by Nahdlatul Ulama and Muhammadiyah Banyuwangi. Some schools owned by Nahdhatul Ulama include Masyitoh Kindergarten, Madrasah_Ibtidaiyah (elementary), Madrasah_tsanawiyah (junior high school), and Madrasah_Aliyah (senior high school). In comparison, schools belonging to Muhammadiyah include TK Aisyiyah Bustanul Athfal, Muhammadiyah Elementary School, Junior High School of Muhammadiyah, Senior High School of Muhammadiyah. The new school enrollment season this year coincides with the presence of the COVID-19 pandemic. This pandemic condition is a challenge for advertising.

For this reason, the unique message design in the admission advertisement with entitled COVID-19. These schools advertise that in anticipation of COVID-19
(4) Laundry services provided special prices during the pandemic with a free delivery service bonus in a specific area.

transmission, they provide fast online new student enrollment. Moreover, offering pickup service for registration documents to prospective student's homes, health insurance coverage, discounted study costs for COVID19 affected families, facilities for online learning, and readiness for new habits in applying health protocols.

The discussion about local content production, radio programming, financial benefits, local communities, ethnicity as a market, and the commodification of local art and culture is embedded with the concepts of the political economy of the media. The political economy of media is one perspective in the study of media Marxists. Three essential concepts to bring the Marxist study of the media are commodification and commercialization, structuration, and spatialization. According to Karl Marx, commodity commodification is related to how the process of transforming goods and services and their use-value into a commodity that has an exchange rate in the Market(Mosco, 2009). The process of adding commodity values to get considerable profits. Value-added through commodification determined by radio programs' ability to meet the individuals' need and the broader listening community. The concept of commercialization is always present in tandem with commodification, as a process of organizing and adjusting the media's structure and content to the audience wants so that media content is profit-oriented solely.

Structuration describes the process of social change in the media. The term social structure, in this case, adopts Anthony Giddens's structuration theory. Those agencies mutually enforce social structures' standing and development; even each part of the structure can serve the other parts(Giddens, 1984). Structuration describes the relationship of ideas between agencies, society, social processes, and social practices (Achmad, 2020a; Giddens, 1990). Forming 
and developing Sritanjung FM towards institutions operating in a network or broadcast society by utilizing an internet communication platform is not carried out independently by radio management. However, it is enforced by human capabilities (radio workers and listeners) as a social agency that produces and reproduces radio structures in the network society.

The concept of spatialization is related to the media's ability to present their products to the audience in terms of space and time. In this context, the institutional structure of Sritanjung FM determines its role in the speed of delivery of media products to listeners and its ability to develop itself as a network institution. It is interesting to link Vincent Mosco's notion of spatialization with Henri Levebfre's opinion of spatialization as the institutional extension of corporate power in the communication Industry(Castells, 2020; Lefebvre, 1991). Whatsapp group and Facebook as virtual space provided by Sritanjung FM, are still limited to being used for content channels. Lefebvre's level as a complex social construction has not shown a struggle for the influence of space and perceptions that lead to supervision and domination of space.

\section{CONCLUSION}

Advertising on Sritanjung FM is proven to increase sales of products and services. Cultural programs and Islamic propaganda become the program of choice for advertising. Local advertisers need advertisements that understand the sociocultural context of the target community. The creative workers on Sritanjung FM can translate the wishes of local advertisers in the form of ad spots and adlibs with the Osing culture's identity. Not surprisingly, many local advertisers trust Sritanjung FM as an advertising medium.

In addition to considering the superiority of cultural content and Islamic proselytizing, the reach of listeners to foreign countries, the adoption of broadcast technology via Facebook and audio streaming by Sritanjung FM, also influenced local advertisers' decisions. Facebook and audio streaming give opportunities in the dynamics of commercial growth and a profit source for the management of Sritanjung FM. As a cultural radio, Sritanjung FM finds that markets and audiences of commercial value are broad, specific markets with local language and cultural characteristics.

The creativity of the production of ad spots and adlibs at Sritanjung FM helped increase financial profits during the COVID19 pandemic. The increase in new local advertisers and increasing frequency of advertisements show the high potential growth of the local content market. Local advertisers scramble to advertise on Osing cultural content programs and Islamic da'wah. Osing cultural programs have meant not limited to the use of Osing language for broadcasts and advertisements, or merely the coverage of Osing ethnic art activities. The Osing cultural program includes values, norms, and lifestyles that align with Osing's ethnic identity and become a legacy for the next generation. Osing language advertising messages and themed COVID-19 pandemic have contributed to driving the Banyuwangi economy.

\section{REFERENCES}

Achmad, Z. A. (2019). Integrasi Program Dakwah dan Budaya: Studi Etnografi Virtual Mediamorfosis Radio Nada FM Sumenep Madura. Jurnal Komunikasi Islam, $\quad 09(2), \quad 238-263$. https://doi.org/10.15642/jki.2019.9.2.23 9-263

Achmad, Z. A. (2020a). Anatomi teori strukturasi dan ideologi jalan ketiga Anthony Giddens. Translitera: Jurnal Kajian Komunikasi Dan Studi Media, 9(2), 45-62.

Achmad, Z. A. (2020b). Mediamorphosis: Understanding New Media (review). In E. R. Nawangsari \& A. Kriswibowo (Eds.), Potret Masyarakat dan Kebijakan Pemerintah Menghadapi Tantangan Pandemi Covid-19. Surabaya: Penerbit Administrasi Negara. 
Achmad, Z. A. (2020c). Pergeseran Relasi Antara Pendengar Radio dengan Institusi Radio dalam Masyarakat Jaringan (Studi Etnografi Virtual pada Radio-radio Budaya di Jawa Timur yang Bermediamorfosis). Universitas Arilangga.

Achmad, Z. A., \& Ida, R. (2018). Etnografi Virtual Sebagai Teknik Pengumpulan Data dan Metode Penelitian. The Journal of Society \& Media, 2(2), 130 145.

https://doi.org/10.26740/jsm.v2n2.p130145

Achmad, Z. A., \& Ida, R. (2019). The shifting role of the listeners in the mediamorphosis process of culture radio: A case study of Jodhipati 106.1 FM. Masyarakat, Kebudayaan Dan Politik, 32(3), 240. https://doi.org/10.20473/mkp.v32i32019 .240-250

Achmad, Z. A., Kinan, J. G., \& Artaria, M. D. (2018). Controversy on the Acceptance of Transgender Characterization in the Movie "Lovely Man". The International Post-Graduate Conference on Media and Communication (IPCOMC), 360-365. Surabaya: SCITEPRESS - Science and Technology Publications, Lda.

Achmad, Z. A., Mardliyah, S., \& Pramitha, H. (2018). The Importance of Parental Control of Teenagers in Watching Anime with Pornographic Content on the Internet. Proceedings of the International Conference on Contemporary Social and Political Affairs (IcoCSPA 2017). https://doi.org/10.2991/icocspa17.2018.22

Achmad, Z. A., Wiranata, I. M. A., \& Mardliyah, S. (2016). Teenagers are Subjected to Cyber Bullying in Social Media Ask.fm. RE-EXAMINING GOVERNANCE: STRENGTHENING CITIZENSHIP IN THE CHANGING WORLD, ICoCSPA 2016, 435-441. https://doi.org/978-602-18461-4-8

Al-Rawi, A. (2016). Understanding the Social Media Audiences of Radio Stations. Journal of Radio \& Audio Media, 23(1), 50-67. https://doi.org/https://doi.org/10.1080/1 9376529.2016.1155298

Angelone, L. (2018). Virtual Ethnography: The Post Possibilities of Not Being There. Mid-Western Educational Researcher, 31(3), 275-295.

Arps, B. (2009). Osing Kids and the banners of Blambangan, Ethnolinguistic identity and the regional past as ambient themes in an East Javanese town. Wacana, 11(1), 1-38.

Castells, M. (2020). Network of Outrage and Hope: Social Movements in The Internet Age. Cambridge: Polity Press.

Dresang, E. T., \& Koh, K. (2009). Radical Change Theory, Youth Information Behavior, and School Libraries. Library Trends, 58(1), 26-50. Retrieved from http://hdl.handle.net/2142/15294

Ellison, N. B., Steinfield, C., \& Lampe, C. (2007). The Benefits of Facebook "Friends:" Social Capital and College Students' Use of Online Social Network Sites. Journal of Computer-Mediated Communication, 12(4), 1143-1168. https://doi.org/10.1111/j.10836101.2007.00367.x

Faizah, Z. (2011). Pendidikan Islam dalam persepsi masyarakat Using di Desa Karangbendo Kecamatan Rogojampi Kabupaten Banyuwangi. Universitas Islam Negeri Sunan Ampel Surabaya.

Featherstone, M. (1995). Undoing Culture: Globalization, Postmodernism and Identity. London: Sage Publications Ltd.

Featherstone, M. (2007). Consumer culture and postmodernism. https://doi.org/10.4135/9781446212424

Fensi, F. (2019). Paradoxic Language 'Cebong-Kampret' in Facebook As a Mirror of the Political Language of Indonesia. Bricolage: Jurnal Magister Ilmu Komunikasi, 5(02), 103. https://doi.org/10.30813/bricolage.v5i02 .1887

Fernando, J., Sya, M., \& Marta, R. F. (2019). Amalgamation as a Strengthening Ethic. MIMBAR: Jurnal Sosial Dan Pembangunan, 35(2), 334-341. https://doi.org/10.29313/mimbar.v35i2. 4863

Fidler, R. (1997). Mediamorphosis: Understanding New Media. Thousand 
Oaks: Pine Forge Press.

Giddens, A. (1984). The Constitution of Society. Cambridge, Massachusetts: Polity Press.

Giddens, A. (1990). The Consequences of Modernity. Cambridge, UK: Polity Press.

Hine, C. (2004). Virtual Ethnography Revisited. Online Reearch Methods, Research Methods Festival. Oxford.

Hine, C. (Ed.). (2005). Virtual Methods: Issues in Social Research on the Internet (1st ed.). Oxford: Berg.

Hine, C. (2015). Ethnography for the Internet: Embedded, Embodied, and Everyday. London: Bloomsbury.

Howitt, D., \& Cramer, D. (2011). Grounded Theory. In Introduction to Research Methods in Psychology (pp. 343-357). Essex: Pearson Education.

KPID Jawa Timur. (2017). Data Lembaga Penyiaran Swasta Radio di Jawa Timur 2017. Surabaya: Komisi Penyiaran Indonesia Daerah Jawa Timur.

Lefebvre, H. (1991). The Production of Space (Translatio; D. Nicholson-Smith, Ed.). Oxford \& Cambridge: Blackwell.

Mosco, V. (2009). The Political Economy of Communication (2nd ed.). London: Sage Publications Ltd.

Mursidi, A., \& Soetopo, D. (2018). Toponimi Kecamatan Kabupaten Banyuwangi: Pendekatan Historis. Banyuwangi: LPPM Universitas PGRI Banyuwangi.

PRSSNI Jawa Timur. (2018). Profil Anggota PRSSNI Jawa Timur. Retrieved 29 June 2018, from http://www.radiojatim.com/index.php?o ption $=$ com $\_$content $\&$ view $=$ article $\&$ id $=1$ \&Itemid $=154 \#$

Rahim, S. A., \& Pawanteh, L. (2010). The local content industry and cultural identity in Malaysia. Journal of Media and Communication Studies, 2(10), 215-220.

Raj Singh, P. (2011). Consumer Culture and Postmodernism in Postmodern Openings. Postmodern Openings, 2(5), 55-88.

Sade-Beck, L. (2004). Internet Ethnography: Online and Offline. International Journal of Qualitative Methods, 3(2), 45-51.

https://doi.org/10.1177/1609406904003 00204

Salamun, Sumintarsih, \& Wuryansari, T. E. (2015). Komunitas Adat Using Desa Aliyan, Rogojampi, Banyuwangi, Jawa Timur: Kajian Ritual Keboan. Yogyakarta: Balai Pelestarian Nilai Budaya.

Salo, J., Lankinen, M., \& Mäntymäki, M. (2013). The Use of Social Media for Artist Marketing: Music Industry Perspectives and Consumer Motivations. International Journal on Media Management, 15(1), 23-41. https://doi.org/10.1080/14241277.2012. 755682

Sawyer, R., \& Chen, G.-M. (2012). The Impact of Social Media on Intercultural Adaptation. Intercultural Communication Studies, XXI(2).

Turkle, S. (2011). Life on the Screen: Identity in the Age of the Internet. New York: Simon and Schuster.

Walliman, N. (2011). Research Methods: The Basics. London and New York: Routledge.

Yurisma, D. Y., \& Bahruddin, M. (2020). Pemaknaan Simbol Reog Ponorogo Dalam Tradisi Jawa: Sebuah Kajian Kritis. Bricolage: Jurnal Magister Ilmu Komunikasi, $\quad 6(01), \quad 101$. https://doi.org/10.30813/bricolage.v6i01 .2070 
